13. Постанова КМУ «Про затвердження Порядку проведення інспектування Державною фінансовою інспекцією, ії територіальними органами» від 20.04.2006 № 550. URL : https://zakon.rada.gov.ua/laws/main/550-2006-\%D0\%BF.

14. Наказ Державної судової адміністрації України від 29 липня 2011 р. № 120 «Про затвердження Інструкції про порядок проведення контрольних заходів контрольно-ревізійним відділом Державної судової адміністрації України». URL : https://zakon.rada.gov.ua/rada/show/v0120750-11.

15. Наказ Міністерства праці та соціальної політики України «Про затвердження Інструкції про порядок проведення контрольних заходів Контрольно-ревізійним управлінням Мінпраці» від 10.08.2007 № 429. URL : https://zakon.rada.gov.ua/rada/show/v0429203-07.

16. Гель А.П., Семаков Г.С., Кондракова С.П. Судові та правоохоронні органи України : навчальний посібник. Київ : МАУП, 2004. 272 с.

17. Тевлін Р. Про поняття «правоохоронні органи» у широкому та вузькому розумінні. Радянське право. 1985. № 7. С. 51-54.

18. Загуменна Ю.О. Правоохоронні органи: поняття, ознаки, функції, особливості діяльності. Право і Безпека. 2010. № 3. С. 145-150.

УДК 347.963

DOI https://doi.org/10.32844/2618-1258.2019.5-1.43

ПОДКОПАєВ С.В.

\title{
ТИПОЛОГІЧНА ХАРАКТЕРИСТИКА ПРОКУРАТУРИ УКРАЇНИ
}

У цій статті з позиції інституціонального та функціонального підходу визначаються найбільш суттєві типологічні ознаки прокуратури України, що уможливлюють висновок про неї як особливий вид прокуратури континентального (європейського) типу. Він $є$ перехідним від пострадянської до західноєвропейської моделі.

Розглянуто три основних типи прокуратур, які функціонують у країнах Європи: прокуратура як суб'єкт кримінального переслідування; прокуратура як суб'єкт нагляду за додержанням законів, а також прокуратура змішаного (наглядово-обвинувального) типу.

Автор звертає увагу на зарубіжний досвід, який свідчить про суттєву національну специфіку в правовому регулюванні організації та діяльності інституту прокуратури в різних країнах, що не дає змогу зробити висновок про домінування чи прогресивний характер будь-якої з чинних моделей.

Місце та роль прокуратури в системі публічної влади, що визначається її інституціональною належністю та функціональним змістом, $\epsilon$ одним із головних факторів, які впливають на формування національних моделей прокуратур. Важливим $\epsilon$ i тип кримінального процесу, співвідношення і зміст диспозитивного та публічного начал (принципів) у правозастосовній та правоохоронній діяльності. При цьому кожна конкретна модель $є$ симбіозом кількох типів із превалюванням рис, більшою мірою властивих якомусь із них.

Зміни до Конституції України (у 2016 році) та прийняття у 2014 році Закону України «Про прокуратуру» зумовили зміну організаційної моделі прокуратури. Нині вона втрачає риси прокуратури пострадянського типу через відсутність наглядових повноважень поза кримінальною сферою. Типологічно вона стає ближче до французької (з огляду на ії поліфункціональність) та німецької (враховуючи типологічну наближеність українського кримінального процесу до німецького кримінального процесу) моделей, водночас має такі характерні риси, що дають змогу іiі виокремити в особливий вид: автономність і єдність системи; статус прокурорів, певним чином схожий на суддівський тощо.

Ключові слова: прокуратура, типологія, модель, пострадянська модель, континентальний (європейський) тип.

(c) ПОДКОПАЄВ С.В. - кандидат юридичних наук, доцент, заслужений юрист України 
The article, from the point of view of the institutional and functional approach, identifies the most significant typological features of the Prosecutor's Office of Ukraine, which allow it to be concluded as a special type of prosecutor's office of continental (European) type. It is a transition from the post-Soviet to the Western European model.

Three main types of prosecutors' offices operating in European countries are considered: the prosecutor's office as a subject of criminal prosecution; the prosecutor's office as the subject of law enforcement oversight, as well as the mixed prosecutor's office (supervising type).

The author draws attention to foreign experience, which testifies to the significant national specificity in the legal regulation of the organization and activity of the prosecutor's office in different countries, which does not allow to conclude the dominance or progressive nature of any of the current models.

The place and role of the prosecutor's office in the system of public authority, determined by its institutional affiliation and functional content, is one of the main factors that influence the formation of national models of prosecutors. Also important is the type of criminal process; the ratio and content of dispositive and public principles (principles) in law enforcement and law enforcement activities. In this case, each specific model is a symbiosis of several types with a predominance of features, more or less inherent in any of them.

Changes to the Constitution of Ukraine (in 2016) and adoption of the Law of Ukraine on the Prosecutor's Office in 2014 led to a change in the organizational model of the prosecutor's office. Today, it is losing the features of the post-Soviet prosecutor's office due to the lack of oversight powers outside the criminal sphere. Typologically, it has become closer to the French (given its multifunctionality) and German (given the typological approximation of the Ukrainian criminal process to the German criminal process) models. At the same time, it has such characteristics that allow it to be distinguished in a special form: autonomy and unity of the system; the status of prosecutors, in some ways similar to a judge's, etc.

Key words: prosecutor's office, typology, model, post-Soviet model, continental (European) type.

Вступ. Діяльність прокуратури є одним із видів реалізації державної влади, зумовленої виконанням правоохоронної функції держави. Проведення реформ та оновлення законодавства зумовлюють трансформацію національної моделі прокуратури, ііі ролі в правовій системі держави. При цьому коригування процесу реформ має знаходитися у взаємному зв'язку із вже досягнутим результатом, осмислення якого є можливим і через зіставлення 3 досвідом європейських та інших країн, а також наявною позитивною практикою.

I якщо основні підходи до типології в теорії прокурорської діяльності загалом розкриті $[1$, c. $6 ; 2$, с. $70-75 ; 3$, с. 113$]$, то типологічна характеристика прокуратури з огляду на конституційні та законодавчі зміни потребує дослідження.

Постановка завдання. Метою статті $є$ визначення типологічних ознак та надання типологічної характеристики сучасному інституту прокуратури в Україні, що сприятиме теоретичному осмисленню основ його функціонування та визначенню тенденцій для розвитку.

Результати дослідження. Типологія - це метод наукового пізнання, що грунтується на розчленуванні об'єктів і їх групуванні за допомогою узагальненої моделі або типу. Він використовується з метою порівняльного вивчення суттєвих ознак, зв'язків, функцій, рівнів організації об'єктів як співіснуючих, так і розділених у часі $[4$, с. 88]. Тобто типологія є класифікацією об'єктів за суттєвими ознаками.

До типології прокуратур ще у ХІХ столітті звертався М.В. Муравйов, коли писав, що вони (типи) виробилися шляхом розвитку та поєднання в різних варіаціях (видах) двох інститутів: публічного кримінального переслідування та представництва прав та інтересів корони в державних установах. Власне прокуратура для цілей останнього й остаточно сформувалася, але життя та силу їй дало перше, з яким нерозривно пов'язана ії історія [5, с. 20].

3 високим ступенем узагальнення В.М. Додонов виділяє два типи органів прокуратури (континентальна (європейська) модель) та два типи органів, завдання яких певною мірою відповідні до прокуратури (англо-американська система) [1, с. 8]. 
Щодо останнього, то це юридичні урядові служби в Англії та аторнейські служби США. Варто зазначити, що хоча розвиток правової системи та суспільних відносин в Англії та її колишніх колоніях потребував створення професійного апарату державних обвинувачів, що і було зроблено, головним чином, у вигляді служби Директора публічних переслідувань та пізніше Королівської служби обвинувачення, однак подібні органи, як зазначається в літературі, зберегли «історичний ген» державної адвокатури, що не дає змоги говорити про появу в країнах англійського права прокуратури в її традиційному розумінні [1, с. 6-7]. А кроки на шляху переходу від суто приватної діяльності до служби публічного обвинувачення (прокуратури) були нерішучими [6, с. 80].

Для прокуратури США є характерним більш високий ступінь ії включення в державний апарат на федеральному рівні. Водночас звичне для нас розуміння прокуратури стосовно США буде включати в себе кілька служб і посадових осіб: аторнейську службу, очолювану Генеральним аторнеєм США, який одночасно є міністром юстиції США; соліситорську службу, очолювану Генеральним соліситором США, а також посаду спеціального прокурора. I якщо на федеральному рівні прокуратура являє собою єдину систему органів і посадових осіб, то на рівні штатів та місцевому рівні аторнейські служби є «скоріше професійною корпорацією юристів, що представляє інтереси публічної влади при здійсненні кримінального переслідування та у судових справах», ніж самостійною централізованою службою [3, с. 115].

На європейському континенті державна влада завжди відігравала в житті суспільства більш значну роль, ніж на британських островах. Тому, як зазначається, держави не могли собі дозволити, щоб функцію кримінального переслідування виконували адвокати та, крім того, європейський прокурор завжди розглядався «не як юридичний агент уряду, а як служитель закону, що виступає від імені всього суспільства». При цьому до типів прокуратури континентальної європейської (романо-германської) системи В.М. Додоновим зараховано західноєвропейську модель прокуратури переважно як орган державного обвинувачення, а також «самостійний конституційний орган із широкими повноваженнями» $[1$, с. 8$]$.

До особливих рис сучасної правової системи України належить генетичний зв’язок із романо-германською правовою сім'єю, а також статус правової системи перехідного типу зумовлений іiі соціалістичним минулим і проголошеним курсом на повернення в сім'ю романо-германського права. Водночас визначається, що вона є такою, що «тяжіє до східноєвропейської правової традиції» [7, с. 53-54, 59]. Відповідно, навіть у межах зазначеної правової сім'ї прокуратура України як державна інституція має свою специфіку, що жодним чином не ставить під сумнів доцільність їі типологічної характеристики, в тому числі з урахуванням наявних у країнах романо-германської правової сім’ї моделей прокуратури.

О.В. Воронін звертає увагу на такі два найбільш поширені підходи до типології: функціональний та інституціональний [3, с. 113]. При цьому перший передбачає типологізацію залежно від превалюючої функції прокуратури, другий будується на формальному визначенні іiі місця в системі органів державної влади, яка склалася в тій або іншій країні.

Зазвичай функціональний підхід передбачає виокремлення двох основних типів прокуратури: прокуратура як суб'єкт кримінального переслідування; прокуратура як суб'єкт нагляду за додержанням законів [8, с. 4]. Водночас на прокуратуру будь-якого типу, крім основної функції, може бути покладено реалізацію додаткових функцій, тому є думка про існування прокуратури змішаного типу, для якої характерна наявність кількох функцій [9, с. 45].

Як правило, для європейських моделей прокуратур характерним є кримінальне переслідування ${ }^{1}$, підтримання державного обвинувачення, участь в інших судових справах із метою представництва інтересів держави (публічного інтересу) та, в окремих випадках, реалізація контрольно-наглядових повноважень (лише деяких, певною мірою обмежених). Вони є установами юстиції та організаційно займають двояке становище, з одного боку, адміністративно підпорядковуючись відповідним міністрам юстиції (формально входять до структури виконавчих органів

${ }^{1}$ В Україні, що характерно, Конституція України, Закон України «Про прокуратуру», Кримінальний процесуальний кодекс України не передбачають такої функції прокуратури, не розкривають ії зміст. Водночас у Концепції реформування кримінальної юстиції України (2008р.) зазначено, що державний обвинувач - це посадова особа органів прокуратури, яка здійснює функцію кримінального переслідування особи в процесі досудового розслідування та підтримує державне обвинувачення у кримінальному судочинстві. А кримінальне переслідування - це виключна процесуальна функція прокурора, яка полягає у висуненні від імені держави обвинувачення, направленні кримінальної справи до суду, підтриманні державного обвинувачення в суді, участі у перегляді судових рішень у кримінальних справах в апеляційній та касаційній інстанціях [10]. 
влади), а з іншого - перебувають і реалізують свої повноваження при судах, судових палатах (функціонують у судовій системі).

На відміну від країн англосаксонської правової сім’ї, для європейських прокуратур характерними $є$ певна ступінь централізації та наявність субординаційних зв'язків між прокурорами вищого та нижчого рівнів.

Найбільш типовими представниками континентальної (європейської) моделі прокуратури вважаються прокуратури Франції (Ministère public) та Німеччини (Staatsanwaltschaft). Виокремлюється також радянський (пострадянський) тип прокуратури, зокрема прокуратура Російської Федерації, яка займає особливе місце в типології [11, с. 101].

Французька прокуратура, яка $\epsilon$ класичною моделлю, містить у собі всі головні ознаки, що характерні для прокуратури як органу юстиції. По-перше, це доволі жорстка централізація системи: прокурори республіки (les procureuers de la République), які працюють при трибуналах великого процесу, підпорядковуються генеральним прокурорам (les procureuers générals) при Касаційному, а також генеральним адвокатам (les avocats générals) при апеляційних судах, які призначаються та звільняються Президентом Республіки за рекомендацією міністра юстиції. По-друге, це виконання різних функцій, як-то кримінальне переслідування, підтримання державного обвинувачення, здійснення нагляду за досудовим розслідуванням та поліцейським дізнанням, участь у цивільному судочинстві як самостійної сторони, представництво в суді інтересів виконавчої влади.

Разом із судами (суддями) вони утворюють магістратуру (la magistrature judiciaire), тобто єдиний судовий професійний корпус та особливу форму організації установ юстиції, які формально знаходяться у складі міністерства юстиції, але фактично працюють при різних судах, судових палатах. Діяльність магістратури передбачає взаємозамінність суддів і прокурорів, вони мають єдиний статус. Навіть підготовка суддів і прокурорів проводиться спільно в Національній школі магістратури [6, с. 328].

Під впливом цієї моделі схожі прокурорські системи сформувалися та функціонують в Італії (Publico ministero) та Іспанії (Ministerio Fiscal de España).

Німецька прокуратура так само, як і прокуратура Франції, формально входить до складу міністерства юстиції, але функціонує при Верховному Суді ФРН, верховних судах земель, судах земель та дільничних судах. Прокуратура не залежить від судів, як і суди не залежать від прокуроpiв [6, с. 190]. Хоча прокуратура Німеччини й була створена за французькою моделлю, водночас ії відмінностями $\epsilon$ менша ступінь централізації та більша автономія діяльності прокуратур земель. Крім того, вона відрізняється «більшим нахилом у бік обслуговування інтересів правосуддя» [11, с. 98-101], а основна функція німецької прокуратури полягає у здійсненні кримінального переслідування, що, однак, не позбавляє прокуратуру права на участь у цивільному судочинстві (право порушити позов про визнання шлюбу недійсним, про визнання особи недієздатною; з метою встановлення факту смерті особи, яка вважалася безвісти зниклою).

У Німеччині (так само, як і у Франції) прокурори керують досудовим розслідуванням, здійснюють підтримання державного обвинувачення в суді, беруть участь на стадії виконання вироків та інших судових рішень. Водночас, на відміну від французької моделі, вони володіють більшим обсягом повноважень під час досудового розслідування, а в судовому процесі, хоча й представляють обвинувачення, обмежуються спостережною функцією та, по суті, не беруть участь у судовому слідстві. Фактично, як зазначається в літературі, «прокурор є ніби помічником судді в судовому розгляді» [6, с. 195]. До того ж прокуратура у ФРН практично позбавлена наглядових повноважень.

Своєю чергою, радянська (пострадянська) модель прокуратури займає окреме місце в типології прокуратур, з огляду на іії специфіку, що полягає в наявності широких наглядових повноважень, які є визначальними для інших видів діяльності. Всі інші функції мають похідний та допоміжний характер. Під радянським впливом такий тип організації прокурорської діяльності став визначальним для низки країн.

Нині пострадянську, зокрема російську, прокуратуру зараховують до прокуратури змішаного (наглядово-обвинувального) типу, зазначаючи, що вона - інститут, породжений об'єктивними потребами саме російського суспільства, а головна ії особливість у тому, що вона виконує функції як нагляду за додержанням законів, так і кримінального переслідування [9, с. 45].

Таким чином, зарубіжний досвід свідчить про суттєву національну специфіку в правовому регулюванні організації та діяльності інституту прокуратури, що не дає змоги зробити висновок про домінування чи прогресивний характер будь-якої з діючих моделей. 
Місце та роль прокуратури в системі устрою публічної влади, що визначаються ії інституціональною належністю та функціональним змістом, $є$ одним із головних факторів, які впливають на формування національних моделей прокуратур. Важливими $є$ тип кримінального процесу, співвідношення і зміст диспозитивного та публічного начал (принципів) у правозастосовній та правоохоронній діяльності. При цьому кожна конкретна модель $є$ симбіозом кількох типів із превалюванням рис, більшою мірою властивих якомусь із них.

Українське законодавство закріплює модель, що містить у собі елементи всіх типів із переважанням, донедавна (до 2014 року), наглядового елементу. Тобто прокуратура містила характерні ознаки для прокуратури змішаного типу.

Нині прокуратура в Україні типологічно зберігає свою належність до прокуратури континентального типу, ближче до французької (з огляду на ії поліфункціональність) та німецької (враховуючи типологічну наближеність українського кримінального процесу до німецького кримінального процесу) моделей, водночас має такі характерні риси, що дають змогу її виокремити в особливий вид, який досить умовно можна вважати (назвати) перехідним від пострадянської до західноєвропейської моделі. У будь-якому разі, проведення типологічної класифікації спрямовано не на надання остаточної відповіді про конкретний тип прокуратури (ії через суттєві відмінності в національних правових системах зробити просто неможливо), а на краще теоретичне осмислення основ функціонування цього інституту.

Так, прокуратура в Україні є автономною системою в механізмі державної влади, а судді та прокурори не становлять єдиний професійний корпус. Аналіз конституційних функцій прокуратури (ст. $131^{1}$ Конституції України) щодо підтримання публічного (державного та суспільного - С.П.) обвинувачення, участі при розгляді судом інших справ (представництво інтересів держави у суді у виключних випадках), а так само організації і процесуального керівництва досудовим розслідуванням, забезпечення законності на досудових стадіях кримінального процесу свідчить, що вони покликані, насамперед, сприяти інтересам здійснення правосуддя, тобто цілям, які стоять перед судовою владою [12].

Навіть той факт, що в Конституції України положення щодо прокуратури закріплені в розділі «правосуддя», не змінює характеру її статусу та свідчить скоріше не про зарахування (включення) до судової гілки влади, а про цільову спрямованість їі діяльності на потреби правосуддя як основну функцію судової влади. Це дає змогу говорити, що вона знаходиться при судовій владі. Крім того, хоча статус прокурорів у певній мірі й отримав підвищені гарантії, зміст яких схожий до суддівських, однак він так само має свою специфіку, яка $є$ відмінною від суддівського статусу.

3 одного боку, зазначене можна пояснити традиційною ієрархічною побудовою прокуратури, практикою та тривалими традиціями внутрішньосистемних організаційно-управлінських відносин, а з іншого - специфікою статусу та діяльності органів прокурорського самоврядування та кваліфікаційно-дисциплінарної юрисдикції.

Водночас наглядові повноваження прокурора, не зумовлені діяльністю у кримінальному процесі, Законом України «Про прокуратуру» (2014 року) були скасовані [13], що, своєю чергою, відрізняє ії від пострадянської прокуратури, для якої вони сутнісно характерні.

Слід зазначити, що перебування українських земель протягом XIX-XX століть у складі різних держав (Російської імперії, Австро-Угорщини, Польщі, Чехословаччини), завдяки чому українська правова система відчувала вплив різних правових традицій і різних правових систем, а так само існування Української РСР у складі Радянського Союзу є історичними обставинами, що зумовлюють самобутність вітчизняної правової системи та інституту прокуратури в ній. При цьому найбільший вплив справила саме радянська прокуратура. Змінюючи різні моделі, прокуратура на території України еволюціонувала в загальному контексті історичного розвитку прокурорських систем із суттєвими особливостями, зумовленими специфікою вітчизняного державного управління та кримінального судочинства відповідних історичних епох, що дає змогу виділити їі в окремий вид.

Висновки. Отже, прокуратуру України можна зарахувати до прокуратур континентального (європейського) типу. Водночас вона має характерні риси, які дають змогу виокремити ії в особливий вид - перехідний від пострадянської до західноєвропейської моделі. У цьому сенсі, враховуючи сучасні українські реалії, особливої актуальності набувають питання збереження та посилення ії законоохоронного потенціалу, а отже, перегляду компетенції поза межами кримінальної сфери. 


\section{Список використаних джерел:}

1. Додонов В.Н. Прокуратуры стран мира. Справочник / Под общ. ред. докт. юрид. наук, проф. С.П. Щербы. Москва : Издательство «Юрлитинформ», 2006. С. 6.

2. Кравчук В.М. Інституційно-правовий аспект функціонування прокуратури України як органу державної влади : монографія. Тернопіль : ТзОВ «Терно-граф». 2013. 272 с.

3. Воронин О.В. Об организации и устройстве прокурорской деятельности в некоторых зарубежных странах. Уголовная юстииия. 2018. № 12. С. 113-116.

4. Коновалов С.И., Маркова-Мурашова С.А. Систематизация и типологизация как методологические процедуры правовых исследований. Известия Тульского государственного универсиmema. 2012. № 1. Ч. 2. С. 86-97.

5. Муравьев Н.В. Прокурорский надзор в его устройстве и деятельности: Пособие для прокурорской службы. Прокуратура на Западе и в России. Т. 1. Москва : Унив. тип., 1889. 554 с.

6. Мичко М.I. Прокуратура в країнах світу: історія та сучасність. Монографія / М.І. Мичко, О.М. Толочко. Київ : Національна академія прокуратури України, 2016. 832 с.

7. Порівняльне правознавство : підручник / С.П. Погребняк, Д.В. Лук'янов, I.О. БиляСабадаш та ін. ; за заг. ред. О.В. Петришина. Харків : Право, 2012. 272 с.

8. Семухина О.Б. Типология уголовного процесса англо-американской и романо-германских правовых систем. Томск : Изд-во науч.-техн. лит., 2002. 92 с.

9. Нечевин Д.К. Прокуратура Российской Федерации, ее цели, задачи, функции и основные формы деятельности. Публичное и частное право. 2011. Вып. I (IX). С. 39-46

10. Концепція реформування кримінальної юстиції України: затверджена Указом Президента України від 8 квітня 2008 р. № 311/2008. URL: https://zakon.rada.gov.ua/laws/show/311/2008.

11. Воронин О.В. К вопросу о типе и месте отечественной прокуратуры в системе органов государственной власти. Вестник Томского государственного университета. 2010. № 339. C. $98-101$. B2\%D1\%80

12. Конституція України. URL: https://zakon.rada.gov.ua/laws/show/254\%D0\%BA/96-\%D0\%

13. Про прокуратуру : Закон України від 14 жовтня 2014 p. № 1697-VII. URL: http://zakon0.rada.gov.ua/laws/show/1697-18. 